Ю. В. Козіна

\title{
МОРФОЛОГІЧНІ ЗАСОБИ ВИРАЖЕННЯ КАТЕГОРІЙНОГО ЗНАЧЕННЯ ІСТОТИ / НЕІСТОТИ
}

Козіна Ю. В. Морфологічні засоби вираження категорійного значення істоти / неістоти.

У статті проаналізовано взаємозв'язок категорії відмінка 3 лексико-граматичною категорією істоти/неістоти іменників. Описано послідовність вираження значень субстантивів у формі однини із семою «живий» та «неживий» предмет на рівні закінчень родового, давального та кличного відмінків упродовж писемного періоду розвитку української мови.

Ключові слова: категорія істоти/неістоти, категорія відмінка, морфологічні засоби, давні флексії. 
Козина Ю. В. Морфологические средства выражения категориального значения одушевленности / неодушевленности.

В статье анализируется взаимосвязь категории падежа с лексико-грамматической категорией одушевленности/неодушевленности существительных. Описана последовательность выражения значений субстантивов в форме единственного числа с семой «живой» и «неживой» предмет на уровне окончаний родительного, дательного и звательного падежей на протяжении письменного периода развития украинского языка.

Ключевые слова: категория одушевленности/неодушевленности, категория падежа, морфологические средства, давние флексии.

Kozina Y. V. Morphological means of expressing the categorical meaning of the animate / inanimate.

The article focuses on the relations between the category of case with the lexico-grammatical category of the animate/inanimate of the nouns. The sequence of expression of substantives' meaning in singular with the seme «animate» and «inanimate» object is described on the level of genitive, dative and vocative case endings covering the written period of the Ukrainian language development.

Key words: category of the animate/inanimate, category of case, morphological means, old flexions.

Значення істоти / неістоти на морфологічному рівні виявляються найпослідовніше в протиставленні форм знахідного відмінка у множині. Однак, міжрівнева взаємодія категорії істоти 3 іншими категоріями дозволяє виділити додаткові критерії віднесення субстантиву до класу живих чи неживих предметів. Зокрема зв'язок категорії відмінка у слов'янських мовах із категорію живого/неживого аналізував О. Потебня. Морфологічне протиставлення форм із семантикою істоти та неістоти крізь призму граматичної асиметрії розглядала Т. Мороз. Короткий опис морфологічних засобів вираження семантики істоти в субстантивах поряд із описом засобів інших рівнів у сучасних слов'янських мовах здійснили у своїх працях також О. Ільченко, А. Нарушевич, С. Самійленко. Однак у згаданих працях акцент робився на омонімії флексій саме акузатива, у той час як зв'язок між одиницями мови і об'єктами дійсності (життя) має певний вияв на рівні інших відмінків. На сьогодні відсутня праця, у якій було б описано появу варіативних закінчень у парадигмі відмінювання іменників із семою «живий» та «неживий» предмет. Мета статті дослідити послідовність вираження значення істоти / неістоти на рівні флексій родового, давального та кличного відмінків в іменниках чоловічого роду у формі однини.

Диференціація граматичних сем знаходить формальне вираження в спеціальних флексіях родового відмінка. Так, у сучасній українській мові закінчення - $a$ переважно мають іменники, які позначають назви конкретних предметів (ножа, стола, олівия), назви персоніфікованих предметів (учня, дідуся, викладача), а закінчення -y - назви абстрактних понять, процесів (мітингу, екзамену), назви збірних понять та сукупності людей (люду, ректорату, колективу) тощо. Тобто іменники, що виражають своє граматичне значення за допомогою флексії -y, об'єднані лексичною семою «недискретні, невизначена кількість» [5, с. 23]. Субстантиви 3 таким значенням зараховуються до неістот, тобто можна провести певну межу між іменниками на позначення назв істот та неістот. Проте варто наголосити на тому, що живе не стане неживим від того, що 
вживається 3 іншим закінченням. Ознака, пов'язана 3 формою родового відмінка, є наслідком зміни семантики. «Набуття іменником семи «істота» спричинює можливість варіативності флексій - $а$ і -y: Розума, Мороза, Хмеля (власні імена), але розуму, морозу, шуму» [6, с. 193]. Паралельно флексію, що переважно маркує живі предмети, набувають іменники назви неістот (листа, носа, молока).

Історично іменники чоловічого та середнього роду зберегли давні закінчення $-a,(-я)$. Флексія $-y,(-ю)$ субстантивів чоловічого роду відміни на $*_{-} \breve{o}\left(*_{-j \check{o})} є\right.$ наслідком взаємодії 3 втраченою основою на $* \breve{u}$. У давньоруськоукраїнській та староукраїнській мові форма генітива залежала від характеру давньої основи, пор.: іменники з основою на *-б (*-jŏ): на той гор 女 есть гробъ святаго пророка Самоиля, и отца Слъкана (XII ХД 32); Море же Содомьское мрьтво есть, не имать в себ т никако же животна, ни рыбы, ни рака (58); Откуду се прииде ко мн ъ мати господа моего? (76); нын '九 же иџете ме не слушати. члгіка иже истиноу вамъ глю (1283 СвС 71); пад на ногу старца (XIII/XV КП 2). Іменники

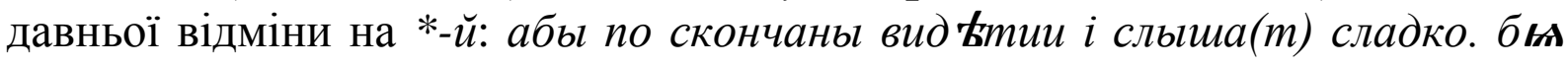
бо словеса паче медоу $і$ ста (1296 СДЯ IV 517); полотрьтиядьслто гривьно сьрьбра ... истины ... пудово м ъду (XIII 517); не погнетши пчель медоу не ъдять (1231/1425 СДЯ IV 518); не ндоуче мась ни медоу пьючи (1280 518); и с тыли миру не держати ми. и со шндреемъ полочккия. и с полочань миру не держати (1386 П 70); мы велики князь Швидрикгяль Руски и иныхъ, чинимъ знаменито... ижъ вид $\mathbf{6 ъ} и$ знаменавъ службу, нам в ърнуою ... которого намъ справы и родъ дому его в врный нашъ князь Сендюшко опов ъдал (1438 ССУМ I 317); а жкосж они записали прерє(ч)ныл(м) кролєм коу ... пєвным слюбо(м), мы кори ижє з божіёго дароу пони(ж) на тыл(x) панств tхх зостали (1488 281). Проте унаслідок уніфікації давніх відмін все частіше простежується змішування, взаємозамінювання флексій. Так іменники з кінцевим приголосним давньої

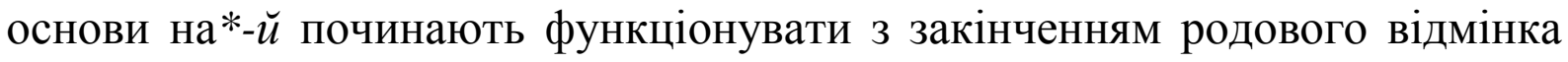
колишньої відміни на*-o (*-jo) і навпаки: $u$ тогда мнози в вроваша $u$ крестилася во имя отца и сына и святаго духа (XII ХД 82); Въ имя Отца и Сына и Святаго Духа (XIII/XV КП 4); А тернаву р ъку имивии с убою стороною оли же до верха р tки то (1377 ССУМ I 166); Одну колоду дають исъ лану. а по два гроша широкан (1386-1418 П 72); тако(ж) по б гро(ш), да плат $\mathbf{b}(m)$, ка(к) старӥи законъ был(л), а о (m) вола гро(ш) платили (1448 ССУМ I 194). Із двох флексій, властивих іменникам сучасної другої відміни чоловічого роду однини $(-a,-y)$, закінчення - $a$ у пам'яках староукраїнської мови мають назви живих істот: $a$ при то(м) бы(л) вєлико(г)о корола зємл Ани(н) па(н) мишко (1463 Рус 41); єсли мя в то (u) хоробє смє (p)ть за (u)дє(m), жона моя милая Фєдора, дочка пана Якова Ко(л)пьто(в)ского, звыччемь хрєстя(н)ски(м) має(т)поховати 
(1571 ГрВол 121); Л $\mathbf{k} т а$ по нарожєню сна божого АФПИ мсиа SI дня (1588 СелРух 80); Гды ж вс $\mathbf{6}$ все можем, а єдин всего знати не может, кром в всемогущаго бога (XVII Велич 71); Иже ребром збоденным явися ревнитель Христовои страсти, и бысть врага поб ъдитель (121); Того ж літа прислан от короля его милости и гетманов коронних реиментаром 3 войсками Лужеикій, каштелян подляскій, в Ладижин до гетмана Ханека (1672 ЛСам 113); и ляхи межи собою турбацію великую міли, не хотячи королем сина Собеского, змерлого короля, и из собою жолніре билися (1696 158); Не було того чоловіка, щоби ся не трвожил, навіть сам король у Варшаві у великой трвозі бул (1619 ЛьвЛ 107); Плачте, очі, слози лийте, Отця й матки не узрите (XVIII УП XVIII 48). Іменники на позначення неживих істот можуть мати закінчення - $a$ або $-y$, бо «у назвах предметів, явищ, процесів, понять виявляються, хоч і не послідовно витримані, дві загальні тенденції» [3, с. 136]: іменники на позначення чітко окреслених предметів, конкретних понять мають у староукраїнській мові переважно закінчення - $а$ (-я): а хто соль вєзеєть $\boldsymbol{\omega}(\mathrm{m})$ воза грошь мыта а коли шминєть гроша давъ єда чєрєсъ єго землю давдиять грошє(и) (1407 Рус 35); а трєти(и) Ставъ ш(m) города мила (1480/1484 42); Ти посіяла зерно, але твоя коса не зачепила колоса (XVII Велич 50). Субстантиви, що означають збірність, масу, речовину, матеріал, абсрактні поняття приймають здебільшого флексію -y (-ю), наприклад: а на тои сторон $\mathbf{t}$ ставоу в смордв ' дворищє бартєничи (1452 Рус 38); Село слобода а в томь сєле дєслть слоугъ на во(и)ноу идоуть и врокоу даю(m) чотыри копь гроше(и) (1471 ССУМ I 200); а тыли бы ждали року а хто бы ихъ хотель габати до року, ты бы ихъ $\boldsymbol{\omega}(m)$ тыхъ борониль ... вылдати не жъдучи року (1487 Рус 43); бу а г̈ колодє мєду прєсного с ключа луиъкого (1488 44); и варити имъ тые ко(р)чмы до того ж году (1489 45); Што за пожиток с того дару, коли я сам и от тебе, диявола, того попрагнул и поискал (XVI Виш 14); Розбите жало об камінь Христовий, Тому не боїться Лазар твого удару (XVII Велич 50). Чітких меж між іменниками 3 семою «неживе» в оформленні форми генітива немає, про що свідчить дібраний фактичний матеріал: а $\tilde{u}$ бочокъ швъса на кони тамъ жо а $\tilde{\phi}$ сти(р)ть сєна зъ дворовъ володими(р)ски(x) (1488 Рус 44); а почати имъ тые ко(р)чмы варитина рокъ на масные запусты великого поста (1489 45); хто бы хотє(л) сєго листу моє(2)о вєдати (1569 ГрВол 35); Зведись із лона Авраамового, як із трону свойого (XVII Велич 50). Іменники на позначення збірних понять, проміжку часу переважно мають закінчення - $a$, іменники з конкретним значенням - флексію -y.

Функціонування різних закінчень в субстантивах чоловічого роду однини у родовому відмінку на позначення неживих предметів простежується і в новій українській мові: Коль кусокъ хлиба падае до долу, треба пиднять, обдуть, почиилувать и ззистьл (1901 Гринч 30); Не 
нальвай квасу у четвергъ, щобъ нищо не топылось (31); Якъ зайде соние, не точы соку, чьл квасу - зминыться (там само); Не тягай зъ квасу яблукь уночи - почорніють (там само); якъ не дойисы куска, то буде за тобою ганяться (там само); Попойившы не облазь кругом стола - блудытымешь и вдень (там само); Дослуживсь до чину, Та й вернувся в село свос I служить покинув (Т. Шевченко) (XIX СУМ XI 325); Марина Василівна межу саду виклала валиком з дерну (І. Сенченко) (ХХ СУМ I 284); Там находився отвір, ведучий до саду Маевських (О. Кобилянська) (316); Мій панотець - князь, великого чину дойшов [дійшов]. (М. Вовчок) (ХХ СУМ XI 325); Упали великі, як горошини, краплини дощу, зашуміла злива, і над морем піднявся туман із бризок (Д. Ткач) (XX СУМ II 138); Вони були в темних, шитих золотою й срібною ниткою свитках, підперезані високими шкіряними поясами з китенями для ножа, огнива, гірстки солі (С. Скляренко) (76).

Отже, у сучасній українській мові вибір закінчення генітива не залежить від типу давньої відміни, до якої його зараховували. Провідним фактором у виборі форми родового відмінка стає семантика субстанива. Закінчення - $a$ приймають усі, без винятку, іменники на позначення живих істот (ця тенденція яскраво простежується в іменниках давньої відміни на*-й син, вол, для яких питомим $є$ закінчення родового відмінка $-y$ ). Проте флексія - $а$ притаманна не лише іменникам на позначення істот, вона наявна і в субстантивах із семою «неживий предмет», але форма родового відмінка у цьому плані залежить від інших сем іменника (збірність / одиничність, конкретність / абстракність тощо). Тобто межі категорії істоти на рівні форм генітива обмежуються поширенням закінчення -y на субстантиви зі значенням неістоти, у той час як флексію - $а$ можна вважати маркером інших лексико-граматичних розрядів іменника. У свою чергу, будь-які зміни семантики слова, зокрема, зумовлені контекстом, мають відбиття на формі генітива іменника. Отже флексію - $а$ можна вважати «слабким діагностичним показником» $[4$, с. 106] у розподілі іменників на позначення живих i неживих предметів, а флексію -y - маркером субстантивів - тільки назв неістот, а, відтак, це лише допоміжні засоби вираження категорії істоти/неістоти у сучасній українській мові.

Значення давального відмінка однини на -y і -ові в українській мові може бути аналогічним значенню родового відмінка на - $a$ i $-y$, тобто пристосоване певною мірою «до розрізнення імен живих і неживих, більшої чи меншої самостійності цих останніх, залежно від вживання» [6, с. 193]. Існує думка, що закінчення -ові (та м'який його варіант -єві) властиве іменникам на позначення істот $[1 ; 2 ; 3]$, що поширення цієї флексії «засвідчують давні пам'ятки передусім у власних назвах та іменниках - назвах істот» [3, с. 89]. Дібраний мовний матеріал вказує на те, що у давньоруськоукраїнській мові іменники чоловічого роду однини, що входять до сучасної другої відміни, мали в давальному 
відмінку різні закінчення: флексію -у (ю) мали іменники давньої основи на

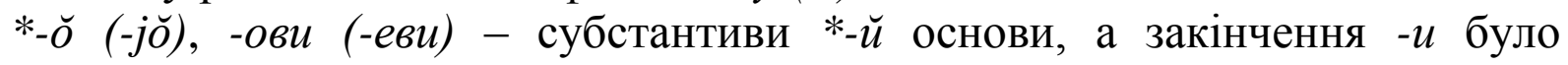
характерне для лексем, що входили до складу давньої відміни на *-i та на приголосний, наприклад: мbl же кляхомся ко царю вашему (912/1377 ЛЛ 36); Гльбу же убьену бывшю и повержену на брез м межи дв колодама (1015/1377 134); Ярославу же не в фдущзю отън с смерти (137); кландюсы ч(с)тимъ иконамъ. кланаюсы древу ч(с)ти(м)у и вслкому кр(c)my (988/1377 СДЯ IV 199); и вънезапноу жена соухороукал поб ъже кь олтарю (XII 342); рыба мншгоншжицл къ какому камени придеть. така плштью қввить(с) (XIII 198). Проте вже у мові XI - XIII ст. непоодинокими $\epsilon$ випадки змішування флексій іменників 3 різними давніми основами: НАко не подобаєть къ олтареви приносити. медоу и мл tка (XII СДЯ IV 343); гітславъ же рече къ бьрнови н tчто мн на

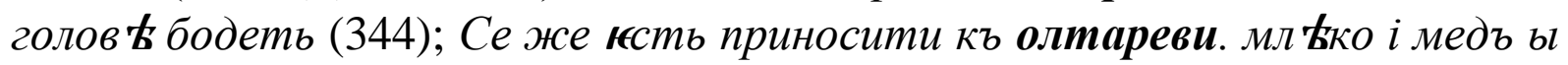
оловину іли медовину (1284 517); Яко приде, повел к кумиры испроврещи, овы ис ъщчи, а другия огневи предати (988/1377 ЛЛ 114); Перуна же повел ' привязати коневи къ хвосту (там само); прид тте, възрадуемъся Господеви, въскликн Ұиъ Богу и Спасу нашему ... въспойте Господеви n tснь нову, воспойте Господеви вся земля; въспойте Господеви, богословите имя его (117); блшеть бо [Владимир] и самь ловечь добрь хороборъ. николи же ко вепреви и ни кмедв ъдеве не ждаше слоугъ свои( $x$ ) (1287/1425 СДЯ IV 516). Факт наявності закінчення -ови (-еви) в іменниках 3 основою на *-б (-jŏ), незалежно від відношення субстантива до категорії живого/неживого, свідчить про автономність вибору флексії в цих субстантивах від семантичних чинників.

У староукраїнській мові в давальному відмінку активно функціонують як закінчення -y (-ю) так і -ови (-еви), та його різновиди -

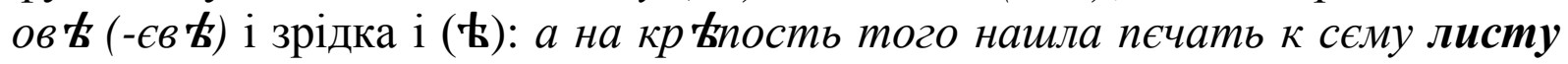
вєл $\mathbf{k} л$ єсми прив ъсити (1388 ССУМ I 532); и слюбуемъ нашею правдою и намею в врою записуемь велебному владиславови кролеви Польскому и его жен т (1393 П 120); а сє я панъ мачина воєвода їлвовъскьи осв ъдчаю ... аже ... ходоро шидловскыи ... продаль пану клюсови свою д фдину на ім шидловь (1400 ССУМ I 532); Се азь рабъ бжӥи кйзь ... поклонихом сж своє(г) ойа гробоу ... и размысли(х) на своє(м) с(д)ции (1446 533); а єщуе кназь Олєксандро пидал сто коп широкых грошєй, чєской монєты братоу своемоу кназю Михайлоу к тымм им тнем (1475 532); и ойь на(ш) король єго мол(с)ть тоє сєло привєрноу(л) $к$ воло(ди)мирю $к$ двороу нашомоу тоуриискоу (1499); Писание до вс tхx обще, в Лядской земли живущчих, да ся покают к богу, показуючи, каковы плоды Лядское земли жителей (XVI Виш 8); у гетмана гуляти и обєдати и през цүалий день гетманові Івану Мазепі з собою сидіти (1696 ЛСам 158); и да(л) быль Іяко(в) шному Гри(и)ку свою сеножа (m) коси (m) (XVII ЛРК 20); для яко(и) бы то 
причины такъ неу(ц)тивіе слова Шапрану и сину его домовля(л) (28); Челов қк к богу ... Ответ божій кчелов ъку (XVII Велич 89); Траф қлося раз королеви Филиппу, иж др қмал на суд (142); Уже и ко самому дерзнуша престолу, и вся иконьл в церкви поверзоша долу (147). Дібраний мовний матеріал демонструє функціонування переважно флексії -y (-ю), що є питомим закінченням іменників 3 давньою основою на *-б (-jŏ), які складали основу сучасної другої відміни. Паралельно закінчення -ови (-еви), первісно притаманне невеликій кількості іменників 3 давньою

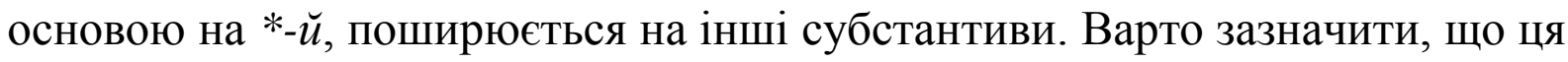
тенденція не пов'язана 3 категорією істоти/неістоти, адже паралельні закінчення можуть мати як субстантиви на позначення живих предметів,

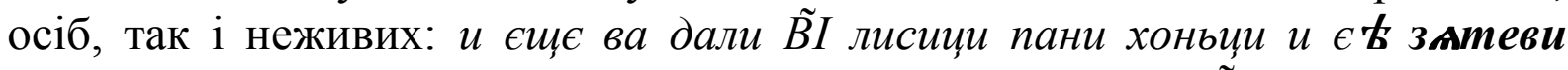

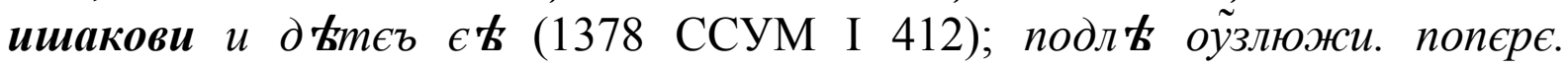
доубровьл. к нєчачюоу л ъсови (1413 Роз 83); и попєрє полА. къ чорномоу л ъсоу. к поток (там само); А зятю моему и дочи тмоей ... не надобе через тот обруб и гранищу ... переходити николи (1472 ССУМ I 412).

Фактичний матеріал, дібраний 3 текстів нової української мови, також вказує на функціонування обох флексій датива в іменниках чоловічого роду однини, проте з перевагою закінчення -ові (-еви): $K$ Енею руки простягає (І. Котляревський) (XIX CУМ IV 63); Йон був в ажитації та щзось з гарячковістю шептав свойому сусідові (М. Коцюбинський) (XIX СУМ I 23); Маркс поклав край поглядові на суспільство, як на механічний агрегат індивідів, щзо допускає всякі зміни з волі начальства (XX 17); Тобі посилку принесуть в хату, ти тільки покажи квитанцію агентові $i$ кажи при собі розкрити ящук, чи не поломили чого (Леся Українка) (15); Саїдові неначе щзось надало агітаційного запалу, $і$ він, запалюючись, викладав єдиному своєму слухачеві науку політграмоти (І. Ле) (20); Він [листоноша] такий педант, щуо тільки в руки адресатові віддає рекомендовані листи (Леся Українка) (21); Виплів батько бриля свому сину (С. Олійник) (455); Увесь день були замуровані вікна, і к вечору мороз рогом поліз (С. Васильченко) (XX СУМ IV 63).

Діалектні матеріали сучасної української мови свідчать про переважне вживання флексії -y (-ю) у східнополіських і середньополіських говорах, а у південно-східному наріччі найпослідовніше вживається закінчення -ові (-еви): Він - цураха му, робйу ус'екі збитки тому чоловіку (ГуцГ 38); а дайут мені ширінку ў рукы тай мойому женнххови (СЗГ 468); Фертик твому пану - ваню в хыжи! (СЛемк 320); Йшов пес през овес - и нич псови, ни вівсови (252); Треба дати шк'іру вуйкови, в'ін файно чинит (СНР 284); Йак бат'ки оддайут', хоч не хоч - до йди, бо батьку понравиусс'я кн'аз' (СПГ 98). Українська мова має варіативні рівнозначні закінчення іменників давального відмінка, вибір яких зумовлений уникненням повторень, певними законами благозвуччя. При цьому флексія -ові (-еви) реалізується переважно в іменниках на позначення істот. 
Компоненти двочленної опозиції істота/неістота протиставляються і на рівні кличного відмінка, різні форми якого найпослідовніше фіксує українська мова. Відомо, що семантика істоти у вокативі реалізується флексіями $-o,-e(-\epsilon),-y(-ю)$ і закріплена в його головній функції адресата потенційного суб'єкта дії [2]. Питому реалізацію істотовості у кличному відмінку репрезентують іменники на позначення живих предметів, адже саме вони є адресатами, які можуть реагувати, мислити, бути виконавцями дії: юдинъ книжник и $р($ ч)є ємоу оучителю идоу по тебе нмио же колиждо

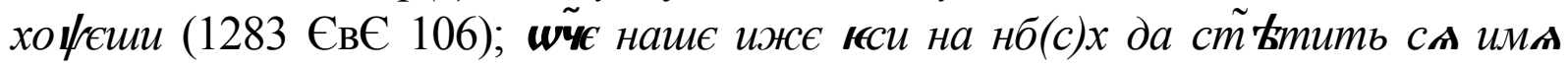
твою (162). У давньоруськоукраїнській мові форма вокатива іменників твердої групи давньої основи на *-о̆ утворювалась за допомогою афікса -е (друже), паралельно м'якої групи на (-jŏ) - за допомогою флексії -ю (оучителю);

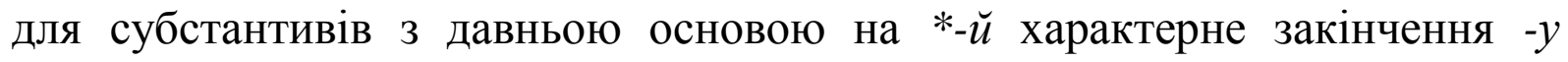

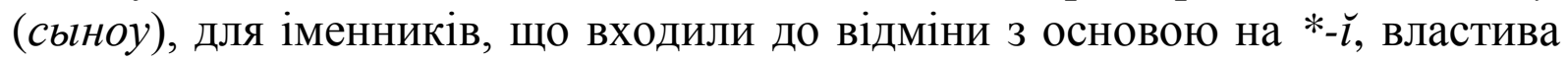
флексія -и (господи). Староукраїнська мова зберігає ці закінчення вокатива: Тебе, агнца, внутр себе, чаю, же ся може съкрушити кровію твоєю, мой боже (XVII Велич 117); Радуйся, земле об ътованная, Радуйся, из нея же течет мед и млеко (70); Ах, снат, ЯР МI, гр тиному, єст сын твой, госпоже, Леч гн ъв той твоя молба укротити може (81); Справцо планет пресвітлих, кролю звізд вщеляких, Вдячних годин одміно, часов не єднаких, Фебе, давщьо світлості, всього світа око, Котрого взрок всю землю займуєт широко (XVII УЛ XVII 254); О ти Острогу, місто справедливоє! (268); - Гетманчику - небоже, Не туди на Запорожжє! (277); Чи не ти, Степанку - сараче, Од козаків гарячий (там само); Не утікай же, ляху, 3 самого перестраху (там само).

Про збереження кличного відмінка свідчать приклади, дібрані 3 текстів нової української мови, діалектних матеріалів сучасної мови, що вказує та те, що флексія вокатива є спадщиною «найдавнішої слов'янської і навіть індоєвропейської старовини» [1, с. 1281]. Наприклад: Тікај Гнате, тікај, брате Да по під рученьками (XVIII - XIX Політ 18); Ој, шипкаре, шипкаре, дај пива і меду (136); Oj, Москальу, ој, Москальу Ој, шчо так худо робиш (132); Вітре буйний, вітре буйний! Ти з морем говориш. Збуди його, заграй ти з ним (Т. Шевченко) (XIX СУМ I 251); Не хилися явороньку, Ще ты зелененькій! Не журися козаченьку, Ще ты молоденькій! (XIX Малорос 3); Ой ты ковалю, коваленьку, Чом ты не куешь рано пораненьку (73); Да не в тй втре да тихенький, Да пов ъй в ътре да буйненькій (там само); Гай-гай, сину, скільки це літ отак не сиділи, Ба й у вічі не бачили один одного (А. Головко) (ХХ СУМ I 75). Форма звертання яскраво простежується і в іменниках жіночого роду: Було 6 тобі, сіромахо, нас трьох не кохати! (XVIII - XIX Політ 136); Марусенько, пани! не правдоньку-жъ ты кажешъ (XIX Малорос 74); Коли любишъ, моя донечко - в ънчайся; А не любишъ, дитя мое - иурайся (77). Попри те, що значення кличного відмінка пов'язане з функцією адресата, 
суб’єкта, істоти (вужче особи), потенційного виконавця дії, спеціальні флексії вокатива властиві всім іменникам чоловічого і жіночого роду, незалежно від їх належності до найменувань класу живих чи неживих предметів. «Позиція кличного відмінка не забезпечує належного протиставлення назв іменників - істот і неістот ні за формою, ні за значенням» [4, с. 107]. Іменники, що на онтологічному рівні мають статус неживих предметів, набувають ознак істоти на синтагматичному рівні, не маючи при цьому протиставлення форм на рівні парадигматики (у функціі знахідного відмінка). Опинившись у функції вокатива такі іменники $є$ синтаксично зумовлені i починають позначати предмети, що сприймаються як живі.

Варіативність флексійного вираження іменників у формі родового, давального і кличного відмінків на позначення як живих, так і неживих предметів, зближення парадигм таких субстантивів, свідчить, по-перше, про хиткість меж між членами цієї опозиції. По-друге, розрізнення значень істоти / неістоти іменників у позиції родового, давального та кличного відмінків не має парадигматичного характеру, а отже, $\epsilon$ зумовленим контекстуально, функціонально (уникнення повторень) залежить від певних законів милозвучності мовлення, що є характерним для української мови. Морфологічні засоби вираження істоти / неістоти найпослідовніше виражені у формах акузатива, флексії інших непрямих відмінків та вокатива є допоміжними.

\section{Література}

1. Булаховський Л. А. Українська мова / Л. А. Булаховський // Вибрані праці : в 5-ти т.- К. : Наук. думка, 1977. - Т. 2. - С. 128.

2. Загнітко А. П. Теоретична граматика української мови : Морфологія : [монографія] / А. П. Загнітко. - Донецьк: ДонДУ, 1996. - 437 с. - Бібліогр. : С. 383-420; С. 422-432.

3. Історична граматика української мови / [Жовтобрюх М. А., Волох О. Т., Самійленко С. П. , Слинько I. I.]. - К. : Вища школа, 1980. - 320 с.

4. Мороз Т. Ю. Семантико-граматична асиметрія морфологічних категорій іменника : автореф. дис. на здобуття наук. ступеня канд. філол. наук : спец. 10.02.01 «Українська мова» / Т. Ю. Мороз Харків - 2008. - 20 с.

5. Озерова Н. Г. Формально-семантическое взаимодействие в морфологических категориях субстантива (на материале русского и украинского языков) : автореф. дис. на соискание науч. степени доктора филол. наук: спец. 10.02.02. «Русский язык» / Н. Г. Озерова / АН УССР. Ин-т языковедения им. А. А. Потебни. - К., 1988. - 40 с.

6. Озерова Н. Г. О. О. Потебня про категорію живого/неживого у східнослов'янських мовах / Н. Г. Озерова // О. О. Потебня й актуальні питання мови та культури: зб. наук. праць. - К. : Видавничий Дім Дмитра Бураго, 2004. - С. 192-196.

\section{Список умовних скорочень використаних джерел}

Велич - Іван Величковський. Твори. Пам’ятки давньої української літератури / Іван Величковський. - К.: Наук. думка, 1972. - 191 с.

Виш - Вишенский И. Сочинения / Подгот. текста, статья и комментарии И. П. Еремина / Вишенский И. М. - Л. : Изд-во АН СССР, 1955. - 372 с.

ГрВол - Волинські грамоти XVI ст. // Пам’ятки української мови XVI ст. - К.: Наук. думка, 1995. - 245 с. Гринч - Гринченко Б. Д. Изъ уст народа. Малорусскіе разсказы, сказки и пр. / Б. Д. Гринченко. Черніговъ: Земская Типографія, 1901. - I - VIII, 1 - 488 с.

ГуцГ - Гуцульські говірки. Короткий словник / [Відп. ред. Я. Закревська]. - Львів, 1997. - 232 с.

ЄвС - «Свсевієве Євангєліє». Наукове видання. Пам’ятки української мови ХІІІ ст / [Відп. ред. В. В. Німчук]. - К., КСУ, 2001. - 320 с. (Серія канонічної літератури).

КП - Абрамович Д. Києво-Печерський патерик. Репринтне видання / Д. Абрамович- К.: Час, 1991 - $280 \mathrm{c}$.

ЛЛ - Льтопись по Лаврентіевскому списку. Изданіе третье Археографической комиссіи. Санктпетербург : Синодальская типография. - 1897. - 512 с. Приложения - 63 с. 
ЛРК - Лохвицька ратушна книга другої половини XVII ст. / [Підгот. до вид. О. М. Маштабей, В. Г. Самійленко, Б. А. Шарпило]. - К. : Наукова думка, 1986. - 222 с.

ЛСам - Літопис самовидця. Джерела з історії України // [Підгот. до вип. Я. І. Дзига]. - К.: Наукова думка, 1971. - $206 \mathrm{c.}$

ЛьвЛ - Львівський літопис // Бевзо О. А. Львівський літопис і Острозький літописець. - К. : Нукова думка, 1970. - С. 99-124.

Малорос - Малороссійскія пьсни / [Изд. М. Максимович]. - М. : Типографія Августа Семена при Императоской Медико-Хирург. Академіи, 1827. - 234 с. I - XXXVI.

П - Грамоти XIV ст. // Пам'ятки української мови / [упор. М. М. Пещак]. - К. : Наук. думка, 1974. $255 \mathrm{c}$.

Політ - Драгоманов М. Політичні пісні українського народу XVIII - XIX ст. Ч.1. / Драгоманов М. Женева: Печатньа «Громади», 1883. - 136 с.

Роз - Українські грамоти (XIV ст. - перша половина XVст.) / [упор. Вол. Розов]. - К. : Українська Академія Наук. - Т. 1. - 1928. - 75 с.

Рус - Українські грамоти XV ст. // Пам’ятки української мови / [упор. В. М. Русанівський].- К. : Наук. думка, 1965. - 162 с.

СДЯ - Словарь древнерусского языка (XI - XIV вв.): В 10 т./ АН СССР. Ин-т рус. яз.; Гл. ред. Р. И. Аванесов. - М.: Рус. яз., 1988. - 526 с.

СелРух - Селянський рух на Україні 1569 - 1647 pp. : [збірник документів і матеріалів]. - К. : Наукова думка, 1993. - 534 с.

СЗГ - I. Сабодош Словник закарпатської говірки села Сокириця Хутського району / Сабодош I. Ужгород : Ліра, 2008. - 480 с.

Слемк - Пиртей П. С. Короткий словник лемківських говірок / П. С. Пиртей; [Упорядкування й підготовка до друку С. Д. Турчин] - Івано-Франківськ : Сіверсія МВ, 2004. - 364 с.

CHP - Гаврило Шило. Наддністрянський регіональний словник / Гаврило Шило. - Львів : Інститут українознавства ім. Крип’якевича НАН України, 2008 (Серія «Діалектологічна скриня»). - 288 с.

СПГ - Лисенко П. С. Словник поліських говорів / П. С.Лисенко; [Відп. ред. Черторизька Т. К.]. - К. : Наукова думка, 1974. - 260 с.

ССУМ - Словник староукраїнської мови XIV - XVI ст. : у 2-х т. - К. : Наук. думка, 1977 - 1978. - T. 1-2.

СУМ - Словник української мови в 10 томах / [П. Й. Горецький, А. А. Бурячок, Г. М. Гнатюк, Н. І. Швидка]. - К. : Наукова думка, 1970.

УЛXVII - Українська література XVII ст. : Синкрет. писемність. Поезія. Драматургія. Белетристика / [Упоряд., приміт. і вступ. стаття В. І. Крекотня]. - К. : Наук. думка, 1987. - 608 с.

УП XVIII - Українська поезія. Середина XVII ст. / [Упоряд. В. І. Скрекотень, М. М. Сулима]. - К. : Наукова думка, 1992. - 680 с.

ХД - Хождение игумена Даниила // Памятники литературы Древней Руси: XII век. - М. : Худож. лит., 1980. - $704 \mathrm{c}$ 